\title{
JAPANESE APOLOGY EXPRESSIONS BY JAVANESE AND SUNDANESE SPEAKERS
}

\author{
Azizia Freda Savana, Wistri Meisa \\ Universitas Muhammadiyah Yogyakarta (UMY), Yogyakarta, Indonesia) \\ E-mail: aziziafreda@umy.ac.id
}

Received: 2021-11-03

Accepted: 2021-12-05

\begin{abstract}
This research discusses expressions of apology in Japanese by Javanese and Sundanese speakers at Universitas Muhammadiyah Yogyakarta. The apology differs between Japanese and Indonesian. Apologizing to the Japanese uses many reasons, the Japanese may distrust the speech partner and cause misunderstanding. In learning Japanese, Javanese-speaking learners are different from Sundanese-speaking learners because their culture also influences them. This research aims to determine the strategy of apology expression by Japanese language learners who speak Javanese and Sundanese as seen from the semantic formula and the differences between the two. This research used a descriptive method with a qualitative approach to describe the strategy of apologizing in Japanese by Javanese and Sundanese mother tongue learners using semantic formulas. Respondents were UMY students from level 2 and level 3 PBJ Study Program with 15 Javanese speaking students and 15 Sundanese speaking students. This research showed that most Japanese learners who speak Javanese and Sundanese tended to use the Speech Act Indication Expression (apology and appreciation) when expressing Japanese apologies. They used polite language ultimately when apologizing to lecturers.
\end{abstract}

Keywords: Semantic Formula, Apologies, Javanese learner, Sundanese Learner, Speech Act Indication Expression.

\section{Introduction}

Language is used to interact with fellow human beings and serves to express feelings and convey information. People develop their language to meet the needs of the culture. Their culture largely influences people's behavior in certain situations. In some instances, what society has done in a specific culture may differ from other cultures.

In learning a foreign language, especially Japanese, the learners must know how to use the language correctly by understanding the culture. Understanding the culture of Japanese society will be more easily achieved by comparing their civilization to see the differences and similarities objectively. The language attitude of society also shows how the people use the language. The differences that arise because of cultural misunderstandings can cause problems in communication.

For example, in an apologizing situation, when someone borrows a book from the teacher and is going to return it, but the book is damaged, he will not bother explaining about it. However, for his mistake, he will offer compensation to solve the problem. In contrast to Indonesians, they may explain first in the details and use the greeting word 
"sensei" to show remorse for damaging sensei's book. Then, they take over responsibility, provide explanations, and offer compensation (Radhiya, 2011). From the example above, Japanese and Indonesians have different ways to express an apology. When one apologizes to the Japanese using many excuses, they can become distrustful of the interlocutor. It could lead to a misunderstanding. This issue can be avoided by learning and understanding the language and the culture at the same time.

Indonesia has various tribes and cultures with different regional languages. The regional language is the first language or mother tongue used as a means of daily communication. At the same time, Bahasa Indonesia is a unifying language. Japanese language learners at Universitas Muhammadiyah Yogyakarta have different mother tongues, and the most common are Javanese and Sundanese. Learning a foreign language is influenced by each other's mother tongue. In learning Japanese, Javanese mother tongue learners are different from Sundanese language learners because of their culture.

In the Javanese language concept, someone who can use the level of speech act correctly has a high level of politeness in their behavior. It happens because there is a positive correlation between speech act with behavior. The more polite someone speaks, the more polite the behavior (Nuryantiningsih \& Pandanwangi, 2018). In vocabulary, Sundanese language civility is familiar with the selection of coarse words and acceptable Words, both subtle for the speakers, slight for the said partner, and lean to the told person. The position determines the selection of polite words user's language, power, familiarity, and the relationship between the role of the speaker and the said partner (Sudaryat \& Nurhadi, 2020).

This research aims to find out how the strategy of apology expression by Japanese language learners who speak Javanese and Sundanese is seen from the semantic formula and the difference between the two.

\section{Literature Review}

Apologizing is an expression of regret for the wrong words and actions committed by the interlocutor to the speaker. Apologies are included in expressive illocutionary speech acts. Austin (in Leech, 1993:16) divided speech acts as follows:

a. Locutionary act: production of utterances

b. Illocutionary act: the intention of utterances

c. Perlocutionary act: the meaning of utterances

Searle (in Tarigan, 2015:42-43) developed a hypothesis that every speech contains speech meaning. Illocutionary action is a central part of speech acts. Searle classified illocutionary speech acts into 5:

a. Assertive: speakers are bound to the truth of the propositions expressed, for example, stating, proposing, boasting, complaining, expressing opinions, reporting.

b. Directive: These illocutions aim to produce effects in the form of actions taken by the speaker, for example, ordering, ordering, begging, demanding, giving advice.

c. Commissive: the speaker is (more or less) bound to act in the future, for example, promising, offering, taking a vow.

d. Expressive: speakers express the psychological attitude of the Speaker to the situation implied in the illocutionary, for example, saying thank you, congratulating, apologizing, and praising. 
e. Declarations: The successful implementation of this illocutionary will result in a match between the content of the proposition and reality, for example, resigning, baptizing, firing, giving names, or imposing sentences.

From the point of view of interpersonal communication, this apologizing speech act impairs the speaker. Thus, the 'burden' for polite language rests more on the speaker because he must take care of the feelings of his interlocutor. In other words, since the speaker hopes that his apology is considered politeness (and behaves in general), he will try to 'persuade' (or can also 'force') his interlocutor to accept his apology as a responsibility. Social responsibility maintains harmonious communication. This method shows positive politeness.

Brown \& Levinson (1987) divided speech politeness into five strategies:
a. Positive strategy
b. Negative strategy
c. Baldly on record
d. Off record
e. Act not chosen

Three factors will significantly influence the realization of the speech above: Social distance (D), as the symmetrical relationship between the speaker and his interlocutor, D shows the level of intimacy and solidarity. It will be reflected in the communication behavior; relative power $(\mathrm{P})$ refers to the level of discretion possessed by the speaker to use his authority over his interlocutor. Thus, an action or utterance will occur or will not happen. This relative power level has various sources, including formal status, wealth, ancestry, age, or gender. The strength of this relative power level can change, depending on the jurisdiction in which a speech occurs and the Absolute ranking of imposition ${ }^{\circledR}$.

In an apology expression, the speaker must use a strategy to apologize. According to Tosborg (1995: 277), there are four apology strategies:

a. Denying responsibility (the apologizer refuses to apologize and avoid being responsible)

b. Acknowledgment of responsibility (the apologizer takes on responsibility implicitly and explicitly and blames himself)

c. Expression of apology (the apologizer shows his apology directly)

d. Explanation or account (the apologizer tries to soften his guilt by explaining)

Meanwhile, according to Blum Kulka et al. (in Savana, 2019), there are five strategies for apologizing as outlined in the semantic formula:

a. Illocutionary Force Indicating Device (IFID) (Saying sorry, thank you). Example: "I am sorry," "Thank you for your concern."

b. Acknowledgment of Responsibility. Example: "I am sorry, it is my fault."

c. An explanation or account of the situation. Example: "I am sorry for not coming to the meeting; I was sick yesterday."

d. Offer of repair. Example: "I am sorry, I will buy a new one"

e. Promise Forbearance. Example: "I am sorry, I will not do it again."

The Javanese language has a level of politeness known as unggah ungguh. Nadar (2019: 136) states that the Javanese language has three styles of language: the informal style 
(ngoko), the semi-official style (madya), and the formal style (krama). The three language styles are based on the level of social factors and relationships. Ngoko language is used when the speaker and the interlocutor have a close relationship. In contrast, madya and krama are used when the speaker and the interlocutor have a higher social status or an ordinary relationship. Apologizing in Javanese will use all three language styles by looking at what the other person is saying and the situation where the apology is made. Apology in Javanese, called nyuwun pangapunten, is a Javanese kromo language with a high level of politeness. Nyuwun ngapuro is an intermediate Javanese language and used by peers and coworkers. Njaluk ngapuro is a Javanese ngoko language and used by close younger friends and colleagues.

Sundanese has a level of politeness known as undak usuk basa. The undak usuk basa is divided into three: basa loma (harsh language), basa lemes (polite language for oneself), and basa lemes (polite language for others) (Arifin, 2016). Basa loma is used for peers and younger people, and the basa lemes is used for older or respected people. There is an apology in Sundanese. Hapunten is the most subtle and polite expression in apologizing and respecting older people in formal situations. Punten is a respectful apology used to pass someone before asking and leaving someone's house, and hampura is the loma language of hapunten (Sari, 2018).

\section{Research Method}

The method used in this study was a descriptive method with a qualitative approach to find out a systematic, factual, and accurate description of the strategy of apologizing in Japanese by Javanese and Sundanese mother tongue learners using a situation-based semantic formula. The data sources were 15 students of Japanese Language Education who speak Javanese and 15 students who talk to Sundanese. The data were collected by purposive sampling by taking samples of level 2 and level 3. The following are the steps of data collection: 1) Asking 15 Javanese-speaking Japanese learners and 15 Sundanesespeaking Japanese learners by making an apology expression using three situations, namely: Apologizing for being late for lectures to the lecturer, apologizing for the dirty borrowed books to seniors, apologizing for not being able to attend the new student admissions meeting to friends; 2) Classifying the data based on the semantic formula Blum Kulka; 3) Analyzing data based on the semantic formulas and language strategies used; 4) Drawing some conclusions.

\section{Results and Discussion}

The data obtained were classified based on the situation and semantic formulas from Blum Kulka's theory:

a. Apologies to the lecturer for being late for class

b. Apologies to seniors because the borrowed book is dirty

c. Apologies to friends for not being able to attend the new student admissions meeting.

The table below is some data on apologies using Japanese from Japanese language learners who speak Javanese.

\begin{tabular}{|c|c|c|c|}
\hline Apology Strategy & Situation 1 & Situation 2 & Situation 3 \\
\hline $\begin{array}{l}\text { Speech Act } \\
\text { Indication } \\
\text { Expression }\end{array}$ & $\begin{array}{l}\text { 遅くなって、すみ } \\
\text { ません。 先生、遅 }\end{array}$ & $\begin{array}{l}\text { 先輩、先輩の-\{をう } \\
\text { っかりに污してー\{当 }\end{array}$ & $\begin{array}{l}\text { ごめん、今回の会議は参 } \\
\text { 加できません。今回の会 }\end{array}$ \\
\hline
\end{tabular}




\begin{tabular}{|c|c|c|c|}
\hline & $\begin{array}{l}\text { れてしまって申し } \\
\text { 訳ございません。 }\end{array}$ & $\begin{array}{l}\text { に申し訳ありませ } \\
\text { ん。先輩の-\{を少し } \\
\text { 污してすみません。 }\end{array}$ & $\begin{array}{l}\text { 議に出席出来なくてすみ } \\
\text { ません。 }\end{array}$ \\
\hline $\begin{array}{l}\text { Recognition of } \\
\text { Responsibility }\end{array}$ & - & 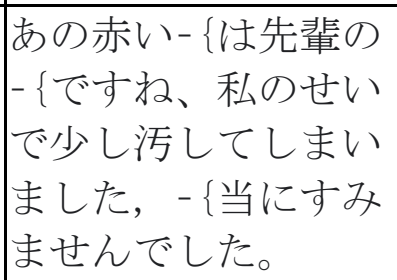 & - \\
\hline $\begin{array}{l}\text { Explanation and } \\
\text { Reason }\end{array}$ & $\begin{array}{l}\text { 先生すみません、 } \\
\text { 交通渋滞で授業に } \\
\text { 遅れました. 先生、 } \\
\text { すみません。㾛坊 } \\
\text { したので遅れてし } \\
\text { まいました。-\{当 } \\
\text { にすみませんでし } \\
\text { た。 }\end{array}$ & & $\begin{array}{l}\text { すみません、新入生歓 } \mathbb{E}\} \\
\text { 会に行けません, その日用 } \\
\text { 事があった。すみません } \\
\text { が、あしたの新入生歓 } \mathbb{E}\} \\
\text { 会の会議に出席できませ } \\
\text { ん, 約束がありますか } \\
ら 。\end{array}$ \\
\hline $\begin{array}{l}\text { Offer For } \\
\text { Compensation }\end{array}$ & - & $\begin{array}{l}\text { 先輩、-\{を少し污し } \\
\text { てしまいました。ご } \\
\text { めんなさい、新しい } \\
\text { のを買って。污れて } \\
\text { すみません、あし } \\
\text { た、新しい-\{を返し } \\
\text { ます。 }\end{array}$ & - \\
\hline $\begin{array}{l}\text { Promises of Self } \\
\text { Control }\end{array}$ & - & - & - \\
\hline
\end{tabular}

Table 1. The Data of Javanese Speakers Apology

Table 1 shows that Javanese-speaking learners apologizing use Japanese in situation 1 using two apology strategies: Speech Act Indication Expression and Explanation and Reason. In situation 2, the students use three apology strategies: Speech Act Indication Expression, Recognition of Responsibility, and Offer for Compensation. In situation 3, two apology strategies are used: Speech Act Indication Expression and Explanation and Reason.

How Sundanese speakers apologize using Japanese are explained in Table 2.

\begin{tabular}{|c|c|c|c|}
\hline $\begin{array}{l}\text { Apology } \\
\text { Strategy }\end{array}$ & Situation 1 & Situation 2 & Situation 3 \\
\hline $\begin{array}{l}\text { Speech Act } \\
\text { Indication } \\
\text { Expression }\end{array}$ & $\begin{array}{l}\text { 遅れたすみませ } \\
\text { んでした。 } \\
\text { 先生、遅れてし } \\
\text { まって申し訳ご } \\
\text { ざいません。 }\end{array}$ & $\begin{array}{l}\text { 先輩ごめんなさい、- } \\
\{\text { を污してしまってご } \\
\text { めんなさい。先輩、 } \\
\text { ごめんなさい。 }\end{array}$ & $\begin{array}{l}\text { ごめんなさい、歓 } \mathbb{E}\} \text { 会には参 } \\
\text { 加できません。明日の新入 } \\
\text { 生歓 } \mathbb{E}\} \text { 会の会議に出席できな } \\
\text { いと思いましした。申し訳あり } \\
\text { ません。わるい、会議に出席 } \\
\text { できない。 }\end{array}$ \\
\hline $\begin{array}{l}\text { Recognition Of } \\
\text { Responsibility }\end{array}$ & - & $\begin{array}{l}\text { せんぱい、この-\{を } \\
\text { きちんと世話しない } \\
\text { ですみません。 }\end{array}$ & - \\
\hline
\end{tabular}




\begin{tabular}{|c|c|c|c|}
\hline $\begin{array}{l}\text { Explanation } \\
\text { and Reason }\end{array}$ & $\begin{array}{l}\text { すみません、体 } \\
\text { が悪かつたの } \\
\text { で、遅れたすみ } \\
\text { ませんです。朝 } \\
\text { 寝坊ですから、 } \\
\text { 遅くなってすみ } \\
\text { ません。 }\end{array}$ & - & $\begin{array}{l}\text { ごめん、りょうしんがきたの } \\
\text { でかいぎにさんかできなか } \\
\text { た。すまない、俺新入生歓 } \mathbb{E}\} \\
\text { 会の会議に出席出来なかつ } \\
\text { た、事故があったから-\{当に } \\
\text { すまなかった。 }\end{array}$ \\
\hline $\begin{array}{l}\text { Offer For } \\
\text { Compensation }\end{array}$ & - & $\begin{array}{l}\text { 先輩、-\{当にごめん } \\
\text { なさい、今度この- } \\
\{\text { をきれいにしてあげ } \\
\text { ます。 }\end{array}$ & - \\
\hline $\begin{array}{l}\text { Promises Of } \\
\text { Self Control }\end{array}$ & - & - & - \\
\hline
\end{tabular}

Table 2. The Data of Sundanese Speakers Apology

Table 2 shows that Javanese-speaking learners and Sundanese-speaking learners apologizing in Japanese for situation one use two apology strategies: Speech Act Indication Expression and Explanation and Reason. In situation 2, the students use three apology strategies: Speech Act Indication Expression, Recognition of Responsibility, and Offer for Compensation. In situation 3, two apology strategies are used: Speech Act Indication Expression and Explanation and Reason.

The following is a graph-based data analysis from 15 Japanese language learners with Javanese speakers and 15 Japanese language learners speaking Sundanese at Universitas Muhammadiyah Yogyakarta.

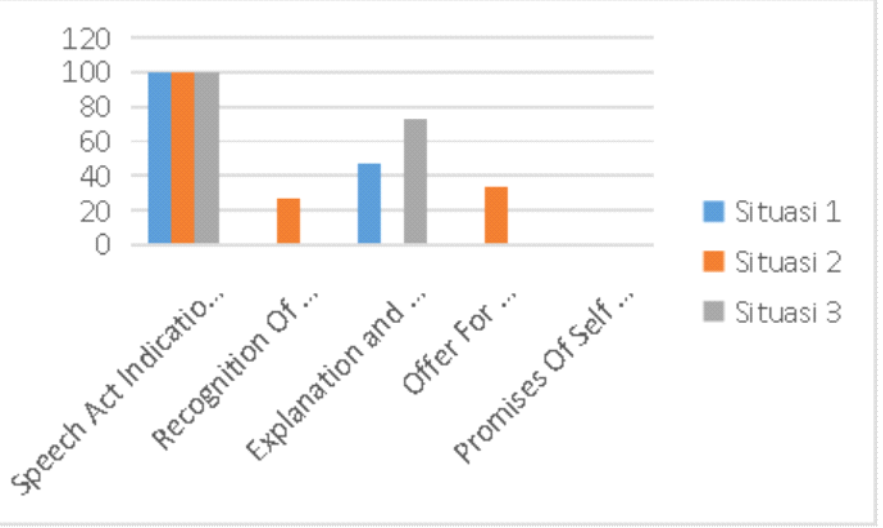

Graph 1. Data on apology strategies for Javanese-speaking learners

Graph 1 shows that all the Javanese-speaking learners in situation 1 use the Speech Act Indication Expression strategy (100\%); Explanation and Reason with 47.3\%; Recognition of Responsibility, Offer for Compensation, and Promises of Self Control is $0 \%$. In situation 2, all respondents use Speech Act Indication Expression (100\%), Recognition of Responsibility with 26.7\%, and Offer for Compensation with 33.3\%, while Explanation and Reason and Promises of Self Control is $0 \%$. In situation 3, all respondents use Speech Act Indication Expression (100\%) and Explanation and Reason strategies with 73.3\%, while Recognition of Responsibility, Offer for Compensation, and Promises of Self Control is $0 \%$. 


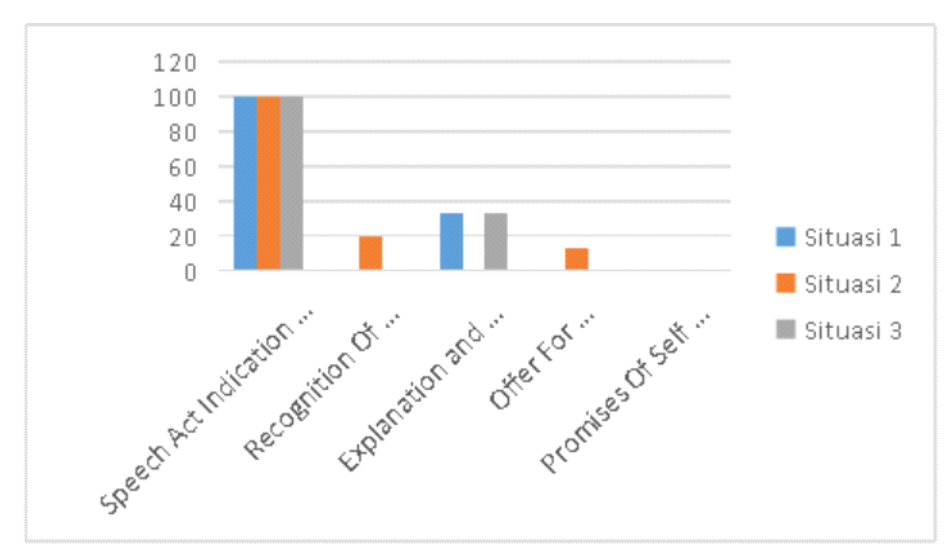

Graph 2. Data on apology strategies for Sundanese-speaking learners

All learners with Sundanese mother tongue in situation 1 use the Speech Act Indication Expression strategy (100\%); Explanation and Reason with 33.3\%; Recognition of Responsibility, Offer for Compensation, and Promises of Self Control is $0 \%$. In situation 2, all respondents used the Speech Act Indication Expression strategy (100\%), Recognition of Responsibility with 20\%, and Offer for Compensation with 13.3\%; Explanation and Reason and Promises of self-control with $0 \%$. In situation 3, all respondents use Speech Act Indication Expression and Explanation (100\%); Reason strategies with 33.3\%; Recognition of Responsibility, Offer for Compensation and Promises of Self Control is $0 \%$.

Based on the semantic formula, Japanese learners who speak Javanese and Sundanese language use Speech Act Indication Expression and Explanation and Reason in situations 1 and 3. In situation 3, they use Speech Act Indication Expression, Recognition of Responsibility, and Offer for Compensation to apologize in Japanese. All students use the Speech Act Indication Expression strategy because apologizing will automatically express the apology words such as Sumimasen, Gomen nasai, Moushiwake arimasen, Moushiwake gozaimasen.

In situation 1, both Javanese and Sundanese speakers use polite language or Keigo because in this situation 1, the speakers (students) apologize to the interlocutor (lecturer) with a higher position. In situation 2, Javanese speakers and Sundanese speakers (85\%) use polite language to apologize to seniors. In situation 3, 70\% of Javanese speakers use polite language, and $60 \%$ of Sundanese speakers use polite language when apologizing to friends. Of the three situations, most Javanese and Sundanese speakers use polite language in apologizing because of guilt to the interlocutor.

\section{Conclusion}

Japanese language learners who speak Javanese and Sundanese at UMY expressed an apology in Japanese in the first situation implemented two strategies, Speech Act Indication Expression and Explanation and Reason, and polite language (Keigo). In the second situation, three strategies were used, Speech Act Indication Expression, Recognition of Responsibility, and Offer for Compensation. The percentage data for the Recognition of Responsibility and Offer for Compensation strategies were more significant than for Javanese speakers. In this situation, $85 \%$ used polite language, and $15 \%$ used ordinary language or futsutai. In the third situation, Speech Act Indication Expression and Explanation and Reason strategy were used with $70 \%$ of Javanese speakers using polite language and $30 \%$ using ordinary language or 
futsutai. In comparison, $60 \%$ of Sundanese speakers used polite language, and $40 \%$ used common language or futsutai.

\section{References}

Arifin, E. Z. (2016). Bahasa Sunda Dialek Priangan. Pujangga, 2(1), 1. https://doi.org/10.47313/pujangga.v2i1.379

Brown, P. \& S. C. L. (1987). Politeness: Some Universals In Language Usage. Cambridge University.

Leech, G. (1993). Prinsip-prinsip Pragmatik. Jakarta: UI Press.

Nadar, F. . (2019). Pragmatik dan Penelitian Pragmatik. Yogyakarta: Graha Ilmu.

Nuryantiningsih, F., \& Pandanwangi, W. D. (2018). Politeness and Impoliteness in Javanese Speech Levels. 166(Prasasti), 383-387. https://doi.org/10.2991/prasasti-18.2018.70

Radhiya, R. J. (2011). Transfer Bahasa Indonesia Terhadap Realisasi Tindak Tutur Meminta Maaf Para Pembelajar Bahasa Jepang. Pendidikan Bahasa Jepang ASPBJI KORWIL JABAR, 4(2), 22-37.

Sari, W. A. (2018). Analisis Kontrastif Ungkapan Meminta Maaf Dalam Bahasa Jepang Dan Bahasa Sunda (Universitas Pendidikan Indonesia). Universitas Pendidikan Indonesia. Retrieved from http://repository.upi.edu/34320/

Savana, A. F., \& Rosiah, R. (2019). Apologies In "Whatsapp" Produced By Japanese Department Student Of Universitas Muhammadiyah Yogyakarta. Izumi, 8(2), 75. https://doi.org/10.14710/izumi.8.2.75-81

Sudaryat, Y., \& Nurhadi, J. (2020). Sundanese Politeness Reposition in Industrial Revolution Era 4.0. 424(Icollite 2019), 51-57. https://doi.org/10.2991/assehr.k.200325.052

Tarigan, H. G. (2015). Pengajaran Pragmatik. Bandung: CV Angkasa.

Tosborg, A. (1995). Request Complaint and Apologies. New York: outon de Gruytar. 